\title{
PENGEMBANGAN BAHAN AJAR MATA KULIAH SEJARAH MADIUN BERBASIS KEMANDIRIAN BELAJAR MAHASISWA
}

\author{
Yudi Hartono \& Esthi Puspitasari*
}

\begin{abstract}
Abstrak
Penelitian ini bertujuan untuk mengembangkan bahan ajar Mata Kuliah Sejarah Madiun. Bahan ajar selama ini masih berupa diktat dan sumber-sumber lain yang bukan diarahkan untuk tujuan pembelajaran. Diktat Mata Kuliah Sejarah Madiun perlu dikembangkan menjadi buku ajar sehingga mendukung kemandirian belajar mahasiswa.

Metode yang digunakan dalam penelitian adalah metode penelitian dan pengembangan atau sering disebut dengan research and development ( $R \& D)$. Penelitian dilakukan dalam dua tahap. Model pengembangan dalam penelitian ini adalah model prosedural. Prosedur atau langkah-langkah penelitian dan pengembangan merujuk pada siklus $R \& D$ dari Borg dan Gall. Indikator capaian dari penelitian ini adalah dihasilkannya naskah buku ajar Sejarah Madiun yang siap terbit. Penelitian ini diharapkan memberi kontribusi pada perkembangan historiografi Madiun dan pembelajarannya terutama di Program Studi Pendidikan Sejarah IKIP PGRI MADIUN.

Berdasarkan pengumpulan informasi dan identifikasi masalah terkait dengan bahan ajar Mata Kuliah Sejarah Madiun di Program Studi Pendidikan Sejarah IKIP PGRI MADIUN. Data dikumpulkan dari dosen pengampu mata kuliah Sejarah Madiun. Beberapa masalah yang teridentifikasi adalah minimnya sumber, masalah pembabakan yang kurang komperehensif, dan kurangnya data kekinian. Masalah-masalah tersebut selanjutnya menjadi acuan untuk mengembangkan bahan ajar Mata Kuliah Sejarah Madiun. Berdasarkan identifikasi masalah tersebut, maka dibuat draf awal bahan ajar Mata Kuliah Sejarah Madiun yang disusun berdasarkan temuan masalah-masalah di lapangan. Setelah melalui uji ahli, uji skala kecil dan skala besar, maka dihasilkan produk akhir bahan ajar Mata Kuliah Sejarah Madiun yang siap dipublikasikan dan diimplementasikan dalam pembelajaran.
\end{abstract}

Kata kunci: Bahan ajar, Sejarah Madiun, Kemandirian Belajar

\footnotetext{
*Yudi Hartono adalah Dosen Pendidikan Sejarah IKIP PGRI MADIUN

Esthi Puspitasari adalah mahasiswa Pendidikan Sejarah IKIP PGRI MADIUN
} 


\section{Pendahuluan}

Madiun merupakan kota bersejarah. Berbagai peristiwa sejarah di masa lalu membangun stereotipikal tersendiri terhadap daerah ini. Persepsi publik belum bisa lepas sama sekali dari dampak kecenderungan hagiografis dalam penulisan sejarah yang menjadi arus utama dalam tiga dekade terakhir. Matra sejarah didominasi oleh peristiwa-peristiwa politik dan tokoh-tokoh yang memiliki akses kekuasaan politik.

Tanpa mengurangi penghargaan terhadap sumbangan penulisan sejarah yang telah dilakukan, keragaman perspektif historis di tingkat lokal penting untuk diwacanakan. Dalam konteks ini, penulisan sejarah dengan pendekatan interdisipliner menjadi penting, tidak saja bagi perkembangan keilmuan sejarah, melainkan juga bagi pendidikan sejarah. Pendekatan interdisipliner berperan penting dalam membangun pemahaman akan kompleksitas suatu peristiwa sejarah. Kuntowijoyo (1994: 121) mengemukakan bahwa kesadaran penggunaan teori dan konsep ilmu sosial akan mampu menjelaskan sejarah secara struktural dalam pola-pola sosial dan dinamika internal yang terdapat di lokalitas.

Satu hal yang penting dicatat di era otonomi dewasa ini adalah pentingnya sejarah lokal. Seperti dicatat oleh Hariyono (1995: 175), pemanfaatan sejarah lokal di tingkat pendidikan manapun akan memungkinkan peserta didik dalam mempelajari sejarah dapat beresonansi dengan aspek eigenwelt yang dimiliki. Penulisan sejarah lokal, menurut Taufik Abdullah (1990: 19) memungkinkan kita untuk berhubungan secara sangat "intim" dengan peristiwa yang sangat lokal dan mungkin selama ini dianggap tidak besar, tetapi sesungguhnya memiliki peran penting dan berharga dalam membentuk peristiwa yang lebih besar.

Pemaparan sejarah secara kontekstual dapat menjembatani peserta didik dalam memahami berbagai peristiwa sejarah di masyarakat sekitarnya dengan peristiwa sejarah di daerah lain. Melalui kajian sejarah lokal, peserta didik dirangsang untuk dapat melihat proses integrasi nasional sebagai suatu peristiwa sejarah.

Program Studi Pendidikan Sejarah IKIP PGRI MADIUN telah lama mengingat pentingnya sejarah lokal sehingga mengintroduksi Mata Kuliah Sejarah Madiun. Sebagai mata kuliah yang relatif baru, bahan ajarnya masih terbatas. Buku teks di perguruan tinggi merupakan komponen penting dalam perkuliahan. Buku teks akan mendukung efektivitas perkuliahan dalam mencapai tujuan pembelajaran. Berbagai metode yang diterapkan oleh dosen dapat dimediasi oleh buku teks. Buku teks juga akan mendorong kemandirian belajar para mahasiswa. Buku teks juga dapat memupuk tradisi akademik dan memperkuat jalinan keilmuan di kalangan civitas akademika perguruan tinggi.

Buku teks sebagaimana ditegaskan dalam Pasal 3 Peraturan Menteri Pendidikan Nasional Republik Indonesia Nomor 2 tahun 2008 Tentang Buku adalah buku acuan wajib untuk digunakan di satuan pendidikan dasar dan menengah atau perguruan tinggi yang memuat materi pembelajaran dalam rangka peningkatan keimanan, ketakwaan, akhlak mulia, dan kepribadian, penguasaan ilmu pengetahuan dan teknologi, peningkatan kepekaan dan 
kemampuan estetis, peningkatan kemampuan kinestetis dan kesehatan yang disusun berdasarkan standar nasional pendidikan.

Sejauh ini yang digunakan adalah diktat dan berbagai buku sumber lain yang tidak ditujukan secara khusus untuk tujuan pembelajaran. Disinilah urgensi dikembangkannya bahan ajar Mata Kuliah Sejarah Madiun sehingga mendukung kemandirian belajar mahasiswa.

Berdasarkan latar belakang di atas, rumusan masalah penelitian ini adalah, "Bagaimanakah pengembangan bahan ajar Mata Kuliah Sejarah Madiun sehingga mendukung kemandirian belajar mahasiswa?"

\section{Tujuan Penelitian}

Penelitian ini bertujuan untuk mengembangkan bahan ajar Mata Kuliah Sejarah Madiun sehingga mendukung kemandirian belajar mahasiswa yang selama ini masih berupa diktat. Diktat Mata Kuliah Sejarah Madiun dikembangkan menjadi buku ajar. Dengan demikian, luaran penelitian ini adalah naskah buku ajar Sejarah Madiun yang siap terbit. Penelitian ini diharapkan memberi kontribusi pada perkembangan historiografi Madiun dan pembelajarannya terutama di Program Studi Pendidikan Sejarah IKIP PGRI MADIUN.

\section{Tinjauan Pustaka}

\section{A. Studi Sejarah Lokal}

Sejarah lokal menurut Taufik Abdullah adalah sejarah dari suatu kelompok atau kelompok-kelompok masyarakat yang berada pada "daerah geografis" yang terbatas (locality), misalnya desa, beberapa desa, atau kecamatan (Taufik Abdullah, 1990:19).

Sejarah lokal mengkaji sejarah masyarakat di tingkat lokal: desa, kecamatan, kelurahan, kabupaten/kota, dan kesatuan-kesatuan masyarakat lokal lainnya (suku/adat). Sejarah lokal mengkaji sejarah berdiri, pertumbuhan dan perkembangan, kemunduran, keruntuhan/kejatuhan suatu masyarakat di tingkat lokal.

Sejarah lokal bisa sekaligus merupakan sejarah daerah. Contohnya adalah sejarah Bali bisa sekaligus merupakan sejarah lokal dan sejarah daerah Bali karena Bali menunjuk pada suatu wilayah administratif politis (provinsi) dan kultural yang sama (kultur masyarakat Bali). Sejarah lokal bisa berbeda dengan sejarah daerah. Contohnya adalah Sejarah Jawa, belum tentu menunjuk sejarah daerah dan sejarah lokal sekaligus karena Jawa saat ini bukan merupakan satu kesatuan administratif politis dan kultural (secara administratif politis Jawa terdiri dari beberapa provinsi/kab/kota, suku dan adat istiadat).

Kecenderungan penulisan sejarah saat ini masih bersifat hagiografis, menampilkan tokoh-tokoh besar, pemikiran-pemikiran besar, dan peristiwaperistiwa besar di lingkup yang luas (nasional, internasional). Peristiwaperistiwa, tokoh, dan pemikiran di tingkat lokal kurang diperhatikan. Tokohtokoh besar, pemikiran-pemikiran besar, dan peristiwa-peristiwa itu belum tentu memiliki pengaruh berarti bagi kehidupan masyarakat lokal.

Penggalian sejarah lokal dan nilai-nilai atau makna sejarah di dalamnya mensyaratkan adanya penelitian sejarah yang dalam level tertentu sesuai 
dengan tujuannya. Dalam hal ini sejarawan dapat mengambil peran dan memberikan sumbangan dengan melakukan kerja profesionalnya. Penggalian itu dapat dilakukan dengan menerapkan standar penelitian sejarah dengan metode sejarahnya, yang terdiri atas empat tahap: heuristik (pengumpulan sumber), kritik (penilaian terhadap sumber), interpretasi (menghubung-hubungkan fakta sejarah), dan historiografi (penulisan sejarah).

Berbagai sumber sejarah baik lisan (sejarah dan tradisi lisan), tertulis (sumber sezaman dan buku), visual (foto dan gambar), maupun benda (artefak) dapat dimanfaatkan untuk kepentingan itu (Garraghan, 1957: 104-123). Wawancara sejarah dan tradisi lisan menduduki posisi yang penting dalam kegiatan itu, karena sejarah lokal seringkali dihadapkan pada keterbatasan sumber-sumber tertulis.

\section{B. Corak Sejarah Lokal}

Menurut Taufik Abdullah (1992) corak sejarah lokal di Indonesia dapat dibedakan menjadi empat golongan:

(1) studi yang difokuskan pada suatu peristiwa tertentu atau studi peristiwa khusus atau evenemental;

(2) studi yang lebih menekankan pada struktur;

(3) studi yang mengambil perkembangan aspek tertentu dalam kurun waktu tertentu atau tematis; dan

(4) studi sejarah umum yang menguraikan perkembangan daerah tertentu (provinsi, kota, dan kabupaten).

Studi yang difokuskan pada suatu peristiwa tertentu atau studi peristiwa khusus atau evenemental contohnya adalah yang dilakukan oleh Sartono Kartodirdjo, "Pemberontakan Petani di Cilegon Banten (1888)," berkaitan dengan masalah struktural yang dihadapi para petani di Banten. Menurut Sartono, bangsa Indonesia sebelum perang sebenarnnya memiliki etos nasionalime berupa rela berkorban. Salah satu contohnya adalah Pemberontakan Petani Banten atau sering juga disebut dengan Geger Cilegon 1888. Masalahnya adalah konflik atas hak-hak tanah antara penduduk dengan pemerintah Hindia Belanda seperti penghapusan tanah-tanah kerajaan, penghapusan tanah-tanah pusaka, serta penarikan pajak atas tanah merupakan salah satu penyebab gerakan protes petani di Banten tahun 1888.

Peristiwa bersejarah itu menjadi bahan disertasinya: The Peasant's Revolt of Banten in 1888, It's Conditions, Course and Sequel: A Case Study of Social Movements in Indonesia yang memperoleh cum laude dari Universitas Amsterdam, Belanda tahun 1966. Studi ini menjadi referensi gerakan sosial dan petani di Indonesia. Penulisan disertasi bertemakan gerakan sosial-dalam hal ini dilakukan oleh para petani yang dipimpin oleh Kyai Wasid dan Jaro Kajuruan didorong oleh hasrat melancarkan protes terhadap penulisan sejarah Indonesia yang konvensional dan Neerlandosentris.

Upaya yang dilakukan Sartono melalui social scientific approach telah memberi pencerahan pada arah historiografi Indonesiasentris. Petani atau orang-orang kecil yang dalam sejarah konvensional menjadi non-faktor, dalam karya Sartono justru menjadi aktor sejarah.

Studi yang lebih menekankan pada struktur contohnya adalah Cliffort Geertz, "Sejarah Sosial Sebuah Kota" (Mojokuto atau Pare, dekat Kediri) tahun 1952-1954. Geertz menangkap gejala sebelumnya dari dualisme: sektor formal yang diwakili sistem perkebunan, dan sektor informal yang merupakan massa 
pendatang dari pedesaan yang masuk ke kota, karena tak bertanah,miskin. Di antara keduanya, ada kelompok priyayi birokrat, pedagang Cina, pedagang santri. Mozaik pengelompkan sosial itu jelas implikasinya dalam ruang geografis kota. Kelompok pengelola kebun enclave di pinggir kota, sekitar kebun dan perkantorannya. Priyayi birokrat di kompleks perumahan (gedung) dan kantornya. Kelompok pedagang Cina, di jalan utama berkelompok dengan toko dan gudangnya. Kaum santri pedagang kecil di kauman (belakang masjid), belakang pasar. Dan perkampungan padat, gubug-gubug bambu berserakan dibelakang dan di antaranya.

Terjadilah dinamika sosial/budaya masyarakat, intra dan antar kelompok, ada upaya kompetisi dan kolaborasi dalam pergulatan ekonomi, sosial, budaya dan politik. Geertz mengenalkan istilah "kota hampa" (hollow town) untuk menggambarkan suatu masyarakat kota yang tidak terintegrasi dan hanya merupakan kombinasi dari komunitas-komunitas kecil. Karena sistem lokal Majokuto itu (seperti daerah umumnya) tak pernah lepas dari pengaruh "dunia luar."

Contoh studi yang mengambil perkembangan aspek tertentu dalam kurun waktu tertentu atau tematis dilakukan oleh Ong Hok Ham, "Priyayi dan Petani di Karisidenan Madiun Abad 19." Madiun sampai dengan tahun 1830 merupakan manca negara dari Mataram Yogya. Pasca perang Diponegoro (1830) Madiun diserahkan kepada Belanda sebagai ganti rugi perang Diponegoro Di Madiun, Belanda mengangkat bupati (regent Chief) dari pejabat kerajaan. Belanda menerapkan konsep bahwa tanah adalah milik negara, bukan milik pribadi. Belanda menerapkan sistem tanam paksa. Akibat tanam paksa, hak atas tanah hilang diganti dengan kuli (coolie = pekerja tanpa keahlian).

Studi sejarah umum menguraikan perkembangan daerah tertentu (provinsi, kota, dan kabupaten). Penulisan sejarah yang menyeluruh yang mencakup berbagai tahap perkembangan sejarah dari suatu daerah tertentu. Contohnya adalah penelitian M. Said tentang Aceh. Penelitian ini akan mengambil corak studi sejarah umum yang menguraikan perkembangan Madiun dari awal perkembangan hingga masa kemerdekaan.

\section{Bahan Ajar}

Kemendiknas (2008) memberikan pengertian beberapa definisi bahan ajar merupakan informasi, alat dan teks yang diperlukan guru/instruktur untuk perencanaan dan penelaahan implementasi pembelajaran. Bahan ajar adalah segala bentuk bahan yang digunakan untuk membantu guru/ instruktur dalam melaksanakan kegiatan belajar mengajar di kelas. Bahan yang dimaksud bisa berupa bahan tertulis maupun bahan tidak tertulis. Bahan ajar adalah seperangkat materi yang disusun secara sistematis baik tertulis maupun tidak sehingga tercipta lingkungan/suasana yang memungkinkan siswa untuk belajar.

AECT (1986) mendefinisikan bahan ajar sebagai bahan pembelajaran yang berupa barang-barang (media atau perangkat lunak) yang berisi pesan untuk disampaikan dengan menggunakan peralatan. Kadang-kadang barang itu sendiri sudah merupakan bentuk penyajian. Bahan ajar dapat dilihat dari dua sudut, yakni sebagai proses dan sebagai produk. Sebagai proses, bahan ajar berfungsi sebagai alat penunjang proses pembelajaran dalam rangka penyampaian bahan pembelajaran kepada mahasiswa. Sebagai produk, bahan ajar merupakan hasil dari serangkaian bahan yang dimuat dalam bentuk buku/media sesuai kurikulum yang berlaku dan sebagai sumber belajar. 
Menurut Joni (1984) bahan ajar menspesifikasi pengalaman belajar dalam bentuk penstrukturan kegiatan pembelajaran yang kaya dengan variasi sehingga dapat memberikan efek pengiring yang sama efeknya dengan pencapaian tujuan-tujuan pembelajaran. Untuk mencapainya, bahan ajar harus mencakup semua bahan, alat, dan cara yang ditata secara sistematis, mahasiswa/siswa tujuan tertentu. Greene dan Petty (dalam Hakim, 2001) menyatakan bahwa bahan ajar harus (1) memberikan petunjuk yang jelas bagi pengajar dan pengelola kegiatan pembelajaran, (2) menyediakan bahan, alat yang lengkap dan diperlukan untuk setiap kegiatan pembelajaran, (3) merupakan media penghubung antara pengajar dan pebelajar, (4) dapat dipakai oleh pebelajar sendiri dalam mencapai kemampuan yang telah ditetapkan, dan (5) dapat dipakai sebagai program perbaikan.

Bahan ajar berbeda dengan buku teks. Kemendiknas (2008) memberikan definisi bahwa "bahan ajar merupakan bahan atau materi pembelajaran yang disusun secara sistematis yang digunakan guru dan siswa dalam KBM", sedangkan buku teks merupakan "sumber informasi yang disusun dengan struktur dan urutan berdasar bidang ilmu tertentu".

Perbedaan bahan ajar dan buku teks dapat disimak pada ciri-ciri keduanya. Pannen \& Purwanto (2001) yang mengacu pendapat Lewis \& Paine menyatakan bahwa bahan ajar memiliki ciri (1) menimbulkan minat dari pembaca, (2) ditulis dan dirancang untuk digunakan mahasiswa, (3) menjelaskan tujuan instruksional, (4) disusun berdasarkan pola belajar yang fleksibel, (5) strukturnya berdasarkan kebutuhan mahasiswa dan kompetensi akhir yang akan dicapai, (6) terfokus pemberian kesempatan mahasiswa untuk berlatih, (7) mengakomodasi kesukaran belajar mahasiswa, (8) selalu memberi rangkuman, (9) gaya penulisan komunikatif dan semi formal, (10) kepadatan berdasarkan kebutuhan mahasiswa, (11) dikemas untuk digunakan dalam proses instruksional, (12) mempunyai mekanisme untuk mengumpulkan umpan balik dari mahasiswa, dan (13) menjelaskan cara mempelajari bahan ajar.

Dengan berpijak pada pendapat Lewis \& Paine, Pannen \& Purwanto (2001) menyatakan bahwa ciri-ciri buku teks adalah (1) mengasumsikan minat dari pembaca, (2) ditulis untuk digunakan dosen, (3) dipasarkan secara luas, (4) belum tentu menjelaskan tujuan instruksional, (5) disusun secara linier, (6) strukturnya berdasarkan logika bidang ilmu, (7) belum tentu memberikan latihan, (8) tidak mengantisipasi kesukaran yang dihadapi mahasiswa, (9) belum tentu memberikan rangkuman, (10) gaya penulisan naratif, tetapi tidak komunikatif, (11) sangat padat, (12) dijual secara umum, (13) tidak memiliki mekanisme untuk mengumpulkan umpan balik, dan (14) tidak memberikan saran-saran cara mempelajari buku tersebut. Namun, pada kenyataannya ada juga bahan ajar yang disusun sedemikian rupa sehingga tidak menjadi buku teks dan tidak menjadi bahan ajar murni.

Mengenai bentuk bahan ajar di atas, sangatlah beragam. Mengacu pendapat Bernd Weidenmann dalam buku Lernen mit Bildmedien, Sulistyowati (2009) mengelompokkan bentuk bahan ajar menjadi tiga, yaitu (1) auditif: radio, kaset, piringan hitam, (2) visual: flipchart, gambar, film bisu, video bisu, program komputer, bahan tertulis dengan dan tanpa gambar, (3) audio visual: berbicara dengan gambar, pertunjukan suara dan gambar, dan film/video.

AECT (1986) menjelaskan bahwa bentuk bahan ajar dapat berupa cetak dan noncetak. Bahan ajar tersebut dapat berupa lima bentuk, yaitu (1) bahan 
cetak, misalnya handout, buku, modul, lembar kerja, brosur, leaflet, wallchart, (2) audio visual, misalnya video/film,VCD/DVD, (3) audio, misalnya radio, kaset, CD audio, (4) visual, misalnya foto, gambar, model/maket, dan (5) multimedia, misalnya CD-interaktif, berbasis komputer, dan internet. Bentuk bahan ajar berupa bahan cetak dapat dikategorikan bahan ajar berbasis cetak, sedangkan bahan ajar berbentuk audio, visual, audio-visual, dan multimedia interaktif dapat dikategorikan bahan ajar berbasis teknologi informasi dan komunikasi.

Dengan kemajuan teknologi informasi dan komunikasi, bentuk bahan ajar semakin beragam. Bahan ajar dapat disampaikan dengan fitur tautan (hyperlink), pemakaian huruf, warna, dan gambar yang dapat beranimasi, serta penggunaan audio-visual yang mendukung materi. Bahan ajar modern dapat berwujudkan buku elektronik (e-book), majalah elektronik (e-magazine), berita elektronik (enews), jurnal elektronik (e-journal), CD/DVD multimedia interaktif model flash atau slide interaktif.

Pembelajaran elektronik (e-Learning) memiliki beragam model. Swajati (2005) menyatakan bahwa model-model e-Learning dapat berupa "tutorial, simulasi, Electronic Performance Support System (EPSS) misal aplikasi Help pada perangkat lunak Microsoft Office, permainan (game) instruksional, tes, pemeliharaan dokumen, dan panduan, serta bisa mengkombinasikan berbagai model". Lebih lanjut dijelaskan Swajati, di masa depan e-Learning akan disampaikan menggunakan Personal Digital Assistant (PDA), misalnya Palm Pilot dan Pocket PC, bahkan lewat piranti wireless seperti telepon seluler. Hal ini merupakan inovasi baru dalam dunia pendidikan. Media ini digolongkan dalam bentuk pembelajaran berbasis ponsel yang disebut sebagai m-Learning (Mobile Learning).

Sajian bahan ajar ini diharapkan mempermudah pengajar dan peserta dalam melaksanakan kegiatan belajar. Dosen/guru bukanlah sebagai sumber segala informasi. Namun, hal ini bukan berarti bahwa kegiatan pembelajaran tidak membutuhkan dosen/guru karena proses perkuliahan tetap menuntut kehadiran dosen/guru walaupun tidak selalu. Mahasiswa/siswa dituntut aktif. Kemasan bahan ajar ini dapat berfungsi sebagai alat untuk mempermudah penyampaian materi yang akan diberikan dosen/guru. Berbagai kemudahan ini diharapkan dapat meningkatkan kualitas perkuliahan untuk mencapai tujuan pembelajaran.

Mahasiswa juga dapat berperan aktif dalam mengembangkan diri. Karakteristik kemampuan reseptif mahasiswa/siswa yang beraneka ragam dalam kecepatan penyerapan materi dapat diwadahi oleh bahan ajar interaktif. Mahasiswa/siswa dapat menentukan perannya sendiri terhadap materi-materi yang dipilih untuk mengulang atau melanjutkan materi berikutnya. Penguasaan materi pembelajaran diharapkan berjalan secara optimal sesuai dengan daya serap tiap mahasiswa/siswa.

Terkait fungsi bahan ajar, setidaknya dapat ditinjau dari pembelajar, pebelajar, dan evaluasi. Fungsi ini mengacu pada pendapat Sulistyowati (2009) berikut ini. Penggunaan bahan ajar berfungsi sebagai (1) pedoman bagi guru yang akan mengarahkan semua aktivitasnya dalam proses pembelajaran, sekaligus merupakan substansi kompetensi yang seharusnya diajarkan kepada siswa, (2) pedoman bagi siswa yang akan mengarahkan semua aktivitasnya dalam proses pembelajaran, sekaligus merupakan substansi kompetensi yang 
seharusnya dipelajari/dikuasainya, dan (3) alat evaluasi pencapaian atau penguasaan hasil pembelajaran.

Bahan ajar terdiri atas dua komponen. Pannen dan Purwanto (2001) menyatakan komponen bahan ajar sebagai berikut.

... (1) tinjauan matakuliah, (2) pendahuluan setiap bab, penyajian daam setiap bab, penutup setiap bab, daftar pustaka, dan senarai. Setiap komponen mempunyai subbab komponen sendiri yang saling berintegrasi satu sama lain.

Cakupan bahan ajar banyak diutarakan daam berbagai referensi. Kementerian Pendidikan Nasional (2008) memberikan cakupan bahan ajar, meliputi "(1) judul, (2) materi pembelajaran, (3) standar kompetensi, (4) kompetensi dasar, (5) indikator, (6) petunjuk belajar, (7) tujuan yang dicapai, (8) informasi pendukung, (9) latihan, (10) petunjuk kerja, dan (11) penilaian".

Mbulu (2004:88) menyatakan bahwa penyusunan bahan ajar harus memuat (1) teori, istilah, persamaan, (2) contoh soal dan contoh praktik, (3) tugas-tugas latihan, pertanyaan, dan soal-soal latihan, (4) jawaban dan penyelesaian tugas-tugas itu, (5) penjelasan mengenai sasaran belajar, contoh ujian, (6) petunjuk tentang bahan yang dianggap diketahui, (7) sumber pustaka, dan (8) petunjuk belajar. Sulistyowati (2009) menyatakan bahwa komponen bahan ajar terdiri atas "(1) petunjuk belajar (petunjuk siswa/guru), (2) kompetensi yang akan dicapai, (3) content atau isi materi pembelajaran, (4) informasi pendukung, (5) latihan-latihan, (6) petunjuk kerja, dapat berupa lembar kerja, (7) evaluasi, dan (8) respon atau balikan terhadap hasil evaluasi. Berdasarkan ketiga pendapat tersebut, dapat disimpulkan bahwa komponen bahan ajar terdiri atas (1) identitas mata kuliah, meliputi judul, materi, kompetensi, indikator, tujuan (2) petunjuk belajar, meliputi petunjuk untuk mahasiswa dan guru, (3) isi materi pembelajaran, (4) informasi pendukung, (5) latihan-latihan, lembar kerja, (6) penilaian, (7) respon/balikan/refleksi.

\section{Kemandirian Belajar}

Belajar mandiri bukan berarti belajar sendiri. Seringkali orang menyalahartikan belajar mandiri sebagai belajar sendiri. Bab II Undang-undang Nomor 20 Tahun 2003 tentang Sistem Pendidikan Nasional (Ikapi, 2003: 15) yang menyatakan bahwa pendidikan nasional berfungsi mengembangkan kemampuan dan membentuk watak serta peradaban bangsa yang bermartabat dalam rangka mencerdaskan kehidupan bangsa, bertujuan untuk berkembangnya potensi peserta didik agar menjadi manusia yang beriman dan bertaqwa kepada Tuhan Yang Maha Esa, berakhlak mulia, sehat, berilmu, cakap, kreatif, mandiri, dan menjadi warga negara yang demokratis, serta bertanggung jawab. Jelaslah bahwa kata mandiri telah muncul sebagai salah satu tujuan pendidikan nasional kita. Karena itu penanganannya memerlukan perhatian khusus semua guru, apalagi tidak ada mata pelajaran khusus tentang kemandirian.

Menurut kamus besar Bahasa Indonesia (Depdiknas, 1988: 625), kemandirian adalah keadaan dapat berdiri sendiri tanpa bergantung pada orang lain. Pengertian belajar mandiri menurut Hiemstra (1994: 1) adalah sebagai berikut:

1) Setiap individu berusaha meningkatkan tanggung jawab untuk mengambil berbagai keputusan. 
2) Belajar mandiri dipandang sebagai suatu sifat yang sudah ada pada setiap orang dan situasi pembelajaran.

3) Belajar mandiri bukan berarti memisahkan diri dengan orang lain.

4) Dengan belajar mandiri, siswa dapat mentransferkan hasil belajarnya yang berupa pengetahuan dan keterampilan ke dalam situasi yang lain.

5) Siswa yang melakukan belajar mandiri dapat melibatkan berbagai sumber daya dan aktivitas, seperti: membaca sendiri, belajar kelompok, latihanlatihan, dialog elektronik, dan kegiatan korespondensi.

6) Peran efektif guru dalam belajar mandiri masih dimungkinkan, seperti dialog dengan siswa, pencarian sumber, mengevaluasi hasil, dan memberi gagasangagasan kreatif.

7) Beberapa institusi pendidikan sedang mengembangkan belajar mandiri menjadi program yang lebih terbuka (seperti Universitas Terbuka) sebagai alternatif pembelajaran yang bersifat individual dan program-program inovatif lainnya.

Dari pengertian belajar mandiri menurut Hiemstra di atas, maka dapat disimpulkan bahwa kemandirian adalah perilaku siswa dalam mewujudkan kehendak atau keinginannya secara nyata dengan tidak bergantung pada orang lain, dalam hal ini adalah siswa tersebut mampu melakukan belajar sendiri, dapat menentukan cara belajar yang efektif, mampu melaksanakan tugas-tugas belajar dengan baik dan mampu untuk melakukan aktivitas belajar secara mandiri.

Menurut Haris Mudjiman (2009: 20-21) kegiatan-kegiatan yang perlu diakomodasikan dalam pelatihan belajar mandiri adalah sebagai berikut:

a) Adanya kompetensi-kompetensi yang ditetapkan sendiri oleh peserta didik untuk menuju pencapaian tujuan-tujuan akhir yang ditetapkan oleh program pelatihan untuk setiap mata pelajaran.

b) Adanya proses pembelajaran yang ditetapkan sendiri oleh peserta didik.

c) Adanya input belajar yang ditetapkan dan dicari sendiri. Kegiatan-kegiatan itu dijalankan oleh siswa, dengan ataupun tanpa bimbingan guru.

d) Adanya kegiatan evaluasi diri (self evaluation) yang dilakukan oleh peserta didik sendiri.

e) Adanya kegiatan refleksi terhadap proses pembelajaran yang telah dijalani peserta didik.

f) Adanya past experience review atau review terhadap pengalaman-pengalaman yang telah dimiliki peserta didik.

g) Adanya upaya untuk menumbuhkan motivasi belajar peserta didik.

h) Adanya kegiatan belajar aktif.

Berdasarkan uraian tentang kegiatan-kegiatan dalam pelatihan belajar menurut Haris Mudjiman di atas, maka dapat diambil kesimpulan bahwa peserta didik yang memiliki kemandirian belajar adalah peserta didik yang mampu menetapkan kompetensi-kompetensi belajarnya sendiri, mampu mencari input belajar sendiri, dan melakukan kegiatan evaluasi diri serta refleksi terhadap proses pembelajaran yang dijalani peserta didik. Dalam keseharian peserta didik sering dihadapkan pada permasalahan yang menuntut siswa untuk mandiri dan menghasilkan suatu keputusan yang baik. Song and Hill (2007: 31-32) menyebutkan bahwa kemandirian terdiri dari beberapa aspek, yaitu :

1) Personal Attributes 
Personal attributes merupakan aspek yang berkenaan dengan motivasi dari pebelajar, penggunaan sumber belajar, dan strategi belajar. Motivasi belajar merupakan keinginan yang terdapat pada diri seseorang yang merangsang pebelajar untuk melakukan kegiatan belajar. Ciri-ciri motivasi menurut Worrel dan Stillwell dalam Harliana (1998) antara lain: (a) tanggung jawab (mereka yang memiliki motivasi belajar merasa bertanggung jawab atas tugas yang dikerjakannya dan tidak meninggalkan tugasnya sebelum berhasil menyelesaikannya), (b) tekun terhadap tugas (berkonsentrasi untuk menyelesaikan tugas dan tidak mudah menyerah), (c) waktu penyelesaian tugas (berusaha menyelesaikan setiap tugas dengan waktu secepat dan seefisien mungkin), (d) menetapkan tujuan yang realitas (mampu menetapkan tujuan realistis sesuai dengan kemampuan yang dimilikinya, mampu berkonsentrasi terhadap setiap langkah untuk mencapai tujuan dan mengevaluasi setiap kemajuan yang telah dicapai.

2) Processes

Processes merupakan aspek yang berkenaan dengan otonomi proses pembelajaran yang dilakukan oleh pebelajar meliputi perencanaan, monitoring, serta evaluasi pembelajaran. Kegiatan perencanaan meliputi: (a) mengelola waktu secara efektif (pembuatan jadwal belajar, menyusun kalender studi untuk menulis atau menandai tanggal-tanggal penting dalam studi, tanggal penyerahan tugas makalah, tugas PR, dan tanggal penting lainnya, mempersiapkan buku, alat tulis, dan peralatan belajar lain), (b) menentukan prioritas dan manata diri (mencari tahu mana yang paling penting dilakukan terlebih dahulu dan kapan mesti dilakukan).

3) Learning Context

Fokus dari learning context adalah faktor lingkungan dan bagaimana faktor tersebut mempengaruhi tingkat kemandirian pebelajar. Ada beberapa faktor dalam konteks pembelajaran yang dapat mempengaruhi pengalaman mandiri pebelajar antara lain, structure dan nature of task.

Berdasarkan pendapat-pendapat di atas dapat disimpulkan bahwa kemandirian belajar merupakan suatu bentuk belajar yang memberikan kesempatan kepada mahassiswa untuk menentukan tujuan belajar, perencanaan belajar, sumber-sumber belajar, mengevaluasi belajar, dan menentukan kegiatan belajar sesuai dengan kebutuhannya sendiri. Aspek yang menunjukkan kemandirian belajar mahasiswa dalam penelitian ini, yaitu personal attributes, processes, dan learning context. Dalam pembelajaran sejarah, kemandirian belajar dapat dilakukan dalam kegiatan berdiskusi. Semakin besar peran aktif mahasiswa dalam berbagai kegiatan tersebut, mengindikasikan bahwa mahasiswa tersebut memiliki kemandirian belajar yang tinggi.

\section{Metode Penelitian}

Metode yang digunakan dalam penelitian adalah metode penelitian dan pengembangan atau sering disebut dengan research and development ( $R$ \& $D$ ). Metode penelitian dan pengembangan merupakan metode penelitian yang digunakan untuk menghasilkan produk tertentu dan menguji efektivitas produk tersebut (Sugiyono, 2006:407). Produk dalam konteks penelitian ini adalah Bahan Ajar Mata Kuliah Sejarah Madiun. 
Terdapat tiga model $R \& D$ yaitu model prosedural, model konseptual, dan model teoritik. Model yang menunjukkan langkah-langkah yang harus diikuti dalam menghasilkan produk merupakan model prosedural. Apabila model yang dihasilkan menyebutkan komponen-komponen produk dan menganilisis komponen secara rinci serta menunjukkan hubungannya, maka model itu merupakan model konseptual. Sedangkan model teoritik akan menggambarkan kerangka berpikir berdasar teori yang relevan dan didukung oleh data empiris.

Model pengembangan dalam penelitian ini adalah model prosedural. Prosedur atau langkah-langkah penelitian dan pengembangan merujuk pada siklus R \& D dari Borg dan Gall (1979:626) sebagaimana tampak pada bagan berikut.

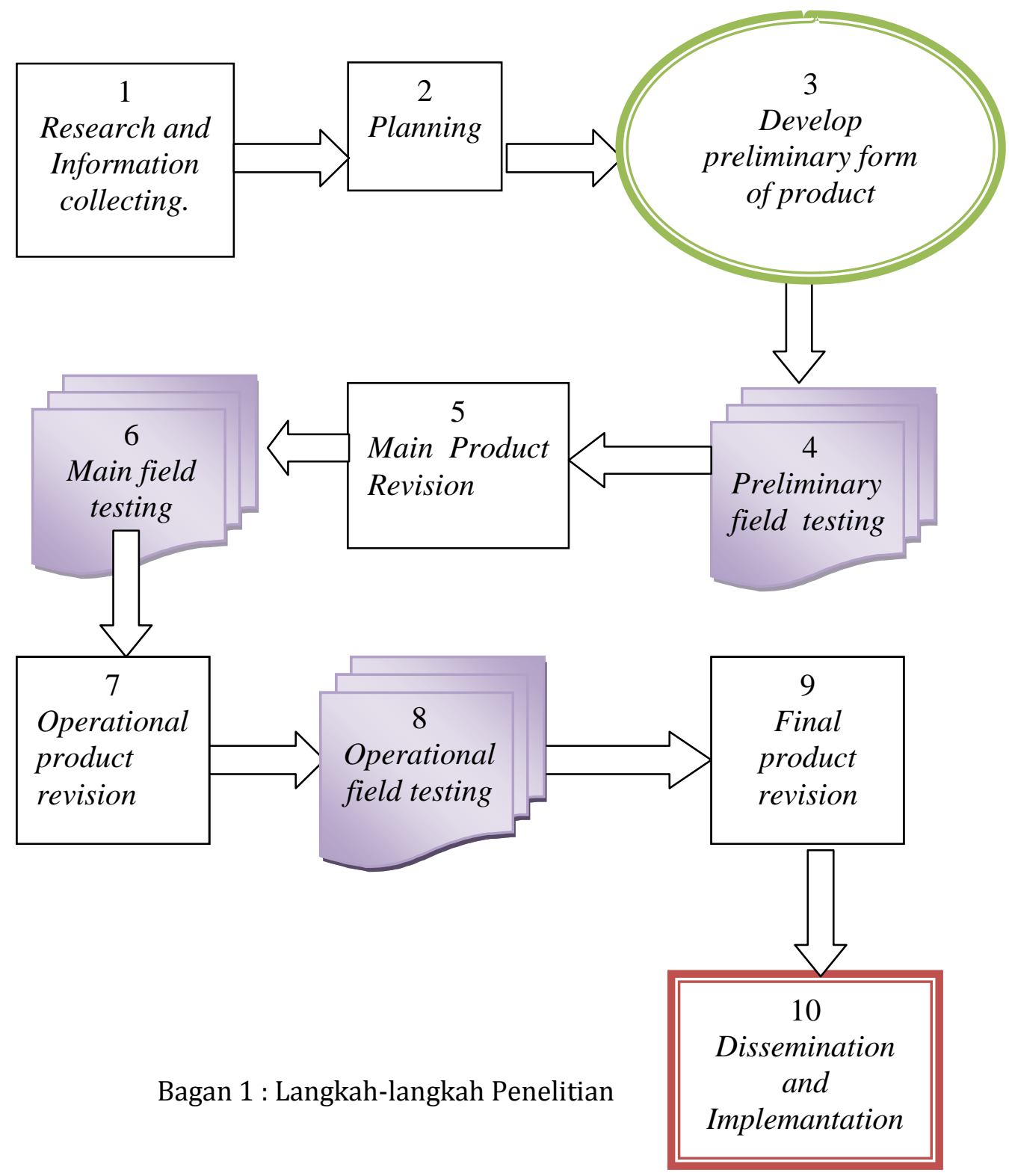


Sebagai langkah awal, dilakukan pengumpulan informasi dan identifikasi masalah terkait dengan bahan ajar Mata Kuliah Sejarah Madiun di Program Studi Pendidikan Sejarah IKIP PGRI Madiun. Data dan informasi diperoleh melalui wawancara dengan Dosen Mata Kuliah Sejarah Madiun. Hasil identifikasi masalah tersebut selanjutnya dikembangkan melalui serangkaian diskusi dengan ahli Sejarah Madiun untuk mengembangkannya sehingga menjadi bahan ajar kemandirian belajar mahasiswa. Hasil kegiatan tersebut adalah draf bahan ajar Mata Kuliah Sejarah Madiun. Draf bahan ajar Mata Kuliah Sejarah Madiun ini kemudian dikembangkan dalam bentuk naskah buku ajar.

Naskah buku ajar Mata Kuliah Sejarah Madiun untuk melihat efektivitasnya dalam mendukung kemandirian belajar mahasiswa. Drat tersebut diujicobakan dalam skala kecil kepada mahasiswa yang diambil secara purposive random. Data dikumpulkan dengan teknik quisioner terbuka, selanjutnya dianalisis secara deskriptif kualitatif. Hasil ujicoba disampaikan kepada ahli untuk memberikan saran perbaikan.

Naskah buku ajar yang telah diujicobakan dalam skala kecil kemudian diujicobakan dalam skala besar kepada mahasiswa Program Studi Pendidikan Sejarah IKIP PGRI MADIUN syarakat Madiun di semua angkatan yang diambil secara purposive random. Data dikumpulkan dengan teknik quisioner terbuka, selanjutnya dianalisis secara deskriptif kualitatif. Hasil ujicoba disampaikan kepada ahli untuk memberikan saran perbaikan. Saran dan data yang masuk digunakan untuk melakukan revisi terhadap produk akhir. Di akhir siklus ini produk buku ajar siap diterbitkan, didesiminasikan dan diimplementasikan. Diseminasi dilakukan melalui penerbitan di Institute Press IKIP PGRI MADIUN untuk disebarluaskan kepada pengguna sebagai hasil penelitian.

Dengan demikian uji coba produk dilakukan sebanyak tiga kali yaitu uji ahli, uji lapangan skala kecil, dan uji coba skala besar. Soenarto (dalam Tim Penatar PPKP, 2005:9) menyebutnya dengan uji ahli atau validasi, uji terbatas, dan uji lapangan.

Indikator capaian dari penelitian ini, dengan demikian adalah dihasilkannya naskah buku ajar yang siap diterbitkan.

\section{Subjek Penelitian}

Penelitian ini melibatkan beberapa pihak, para ahli sejarah Madiun, Dosen dan Mahasiswa Program Studi Pendidikan Sejarah IKIP PGRI MADIUN. Subyek untuk uji ahli dipilih secara purposive, yaitu diambil dengan memperhatikan keahliannya di bidang Sejarah Madiun, sedangkan subyek penelitian untuk uji terbatas dan uji lapangan dipilih dengan purposive random, yaitu dipilih secara acak dengan memperhatikan profil mahasiswa.

\section{Teknik Pengumpulan Data}

Data penelitian ini dikumpulkan dengan wawancara yang dengan para ahli Sejarah Madiun, Dosen, dan Mahasiswa Program Studi Pendidikan Sejarah IKIP PGRI MADIUN. 
Validasi data dilakukan melalui triangulasi teknik, yaitu dengan cara membandingkan data dari satu teknik pengumpulan data melalui angket dengan data yang diperoleh dari wawancara lain. Bila terdapat ketidaksesuaian, maka akan dilakukan konfirmasi dengan subyek penelitian.

\section{Analisis Data}

Analisis data dilakukan dengan metode analisis data kualitatif. Analisis data ditujukan pada data-data yang sifatnya kualitas dan sifat yang nyata diterapkan di lokasi penelitian. Ada dua cara yang digunakan dalam penelitian ini, yaitu analisis isi dan analisis interaktif. Untuk data dokumen dan arsip digunakan analisis isi, sedangkan untuk data hasil wawancara dan observasi digunakan analisis interaktif, seperti dikemukakan Milles dan Huberman (1996). Ada tiga komponen analisis yaitu: reduksi data sajian data dan penarikan kesimpulan. Aktivitas ketiga komponen dilakukan dalam bentuk interaktif dengan proses pengumpulan data sebagai suatu proses siklus. Peneliti hanya bergerak diantara tiga komponen analisis tersebut sesudah pengumpulan data selesai pada setiap unitnya dengan memanfaatkan waktu yang masih tersisa dalam penelitian ini. Untuk lebih jelasnya proses analisis interaktif dapat digambarkan dalam skema sebagai berikut.

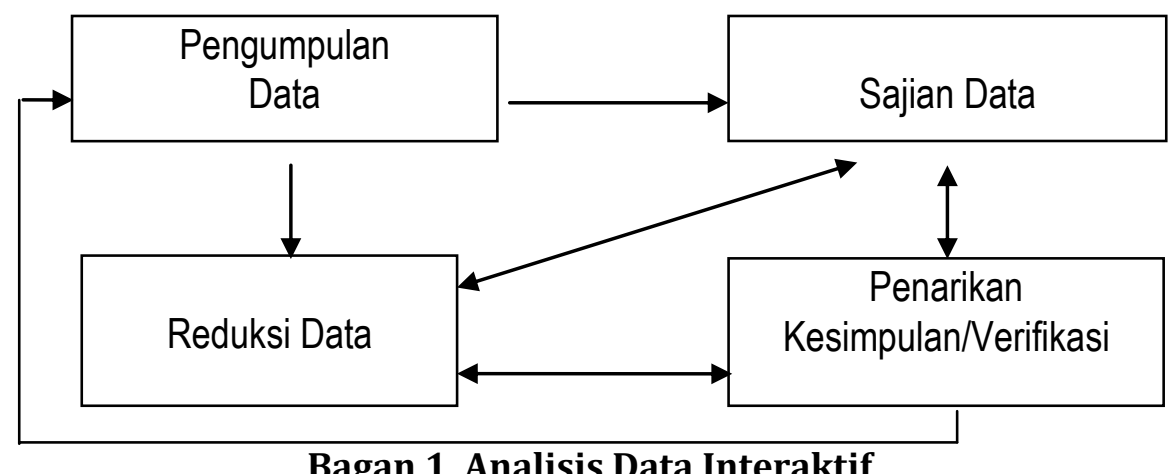

Bagan 1 Analisis Data Interaktif

Data mentah yang terkumpul di lokasi penelitan direduksi, disusun lebih sistematis, dipilih pokok yang penting, difokuskan dan dicari tema dan polanya. Selanjutnya dilakukan reduksi data, yaitu pemilihan, pemusatan perhatian pada penyederhanaan, pengabstrakan, dan transformasi data kasar yang muncul dari catatan-catatan tertulis di lapangan. Sistematisasi data dilakukan dengan membuat sajian data yang berupa tabel, jaringan, atau bagan. Dari sistematisasi data tersebut akan ditemukan pokok-pokok temuan yang penting, tema dan pola yang secara konsisten diterapkan di lokasi penelitian. Temuan-temuan tersebut dijadikan acuan dalam menarik kesimpulan.

\section{Hasil Penelitian dan Pembahasan}

Penelitian diawali dengan pengumpulan informasi dan identifikasi masalah terkait dengan bahan ajar Mata Kuliah Sejarah Madiun di Program Studi Pendidikan Sejarah IKIP PGRI MADIUN. Data dikumpulkan dari dosen pengampu mata kuliah 
Sejarah Madiun. Beberapa masalah yang teridentifikasi adalah minimnya sumber, masalah pembabakan yang kurang komperehensif, dan kurangnya data kekinian. Masalah-masalah tersebut selanjutnya menjadi acuan untuk mengembangkan bahan ajar Mata Kuliah Sejarah Madiun. Hasilnya adalah draf awal bahan ajar Mata Kuliah Sejarah Madiun yang disusun berdasarkan temuan masalah-masalah di lapangan. Draf bahan ajar tersebut selanjutnya disampaikan kepada ahli untuk memberi saran perbaikan. Rekomendasi ahli dapat dilihat pada tabel berikut.

Tabel 1. Rekomendasi ahli

\begin{tabular}{|c|l|l|}
\hline No. & \multicolumn{1}{|c|}{ Komponen } & \multicolumn{1}{c|}{ Saran perbaikan } \\
\hline 1 & $\begin{array}{l}\text { Bagian depan (cober, } \\
\text { daftar isi, kata } \\
\text { pengantar) }\end{array}$ & Judul terlalu provokatif, cover kurang ilustrasi \\
\hline 2 & Tujuan pembelajaran & Rumusan yang lebih operasional dan terukur \\
\hline 3 & Isi per bab & $\begin{array}{l}\text { Perhatikan detail peristiwa. Contoh peristiwa } \\
\text { tertangkapnya Muso }\end{array}$ \\
\hline 4 & Evaluasi/tugas & $\begin{array}{l}\text { Evaluasi mencakup aspek kognitif, afektif, dan } \\
\text { psikomotorik, tugas lapangan }\end{array}$ \\
\hline 5 & Daftar pustaka & Telusuri pustaka kekinian \\
\hline 6 & Lain-lain & - \\
\hline
\end{tabular}

Rekomendasi ahli dijadikan bahan untuk perbaikan bahan ajar. Setelah memperhatikan saran perbaikan dari ahli, selanjutnya naskah bahan ajar Mata Kuliah Sejarah Madiun akan diuji efektivitasnya. Uji coba sekala kecil dilakukan terhadap 5 orang mahasiswa secara random. Berikut rekapitulasi hasil uji coba sekala kecil.

Tabel 2. Rekapitulasi Hasil Uji Coba Skala Kecil

\begin{tabular}{|c|c|c|c|}
\hline No & Komponen & Umpan balik mahasiswa & Keputusan \\
\hline 1 & $\begin{array}{lr}\text { Bagian depan } & \text { (cober, } \\
\text { daftar isi, } & \text { kata } \\
\text { pengantar) } & \end{array}$ & $\begin{array}{l}\text { A1. Judul cukup menarik } \\
\text { namun dapat menimbulkan } \\
\text { pemikiran bahwa Madiun } \\
\text { akan selalu menjadi arena } \\
\text { konflik } \\
\text { B1. Ditambah gambar yang } \\
\text { menarik yang menjadi ciri } \\
\text { khas Madiun, daftar isi dibuat } \\
\text { sub bab agar lebih detail } \\
\text { C1. Format penulisan judul } \\
\text { sebaiknya huruf besar semua, } \\
\text { kata pengantar terlalu } \\
\text { panjang } \\
\text { D1. Judul lebih spesifik agar } \\
\text { tidak menimbulkan tanda } \\
\text { tanva }\end{array}$ & $\begin{array}{l}\text { A1. Diterima } \\
\text { dengan merubah } \\
\text { judul yang tidak } \\
\text { menimbulkan } \\
\text { "tanda tanya" } \\
\text { B1. Diterima } \\
\text { C1. Anak judul } \\
\text { tetap kecil, kata } \\
\text { pengantar } \\
\text { diringkas } \\
\text { D1. Sama dengan } \\
\text { A1. } \\
\text { E1. Daftar isi 1,5 } \\
\text { spasi }\end{array}$ \\
\hline
\end{tabular}




\begin{tabular}{|c|c|c|c|}
\hline & & $\begin{array}{l}\text { E1. Jarak antar baris daftar isi } \\
\text { terlalu berdekatan }\end{array}$ & \\
\hline 2 & Tujuan pembelajaran & $\begin{array}{l}\text { A1. Tujuan sudah sesuai } \\
\text { dengan materinya namun } \\
\text { lebih berkembang bila lebih } \\
\text { divariasikan } \\
\text { B1. Ditambahkan tokoh- } \\
\text { tokoh yang terlibat dalam } \\
\text { sejarah berdirinya Madiun } \\
\text { E1. Penulisan tujuan } \\
\text { pembelajaran perlu dipertegs } \\
\text { lagi, perlu ada penambahan } \\
\text { tujuan pembelajaran }\end{array}$ & $\begin{array}{l}\text { A1. Kurang jelas } \\
\text { yang dimaksud } \\
\text { divariasikan } \\
\text { B1. Diterima } \\
\text { E1. Diterima } \\
\text { dengan } \\
\text { menambahkan } \\
\text { tujuan } \\
\text { pembelajaran }\end{array}$ \\
\hline 3 & Isi per bab & $\begin{array}{l}\text { A1. Perlu penambahan } \\
\text { gambar agar mudah } \\
\text { divisualisasikan oleh } \\
\text { mahasiswa } \\
\text { B1. Perlu ditambah Madiun } \\
\text { masa Reformasi-sekarang } \\
\text { C1. Ditambah gambar sesuai } \\
\text { dengan isi } \\
\text { D1. Ditambah foto-foto } \\
\text { E1. Terlalu memilih kata yang } \\
\text { berlebihan, menggunakan } \\
\text { kosa kata asing yang belum } \\
\text { ada penjelasannya }\end{array}$ & $\begin{array}{l}\text { A1. Diterima } \\
\text { B1. Diterima } \\
\text { C1. Diterima } \\
\text { D1. Diterima } \\
\text { E1. Diterima }\end{array}$ \\
\hline 4 & Evaluasi/tugas & $\begin{array}{l}\text { A1. Lebih baik jika mencakup } \\
\text { aspek kognitif, afektif, } \\
\text { psikomotorik } \\
\text { B1. Perbanyak penelitian } \\
\text { tempat bersejarah di Madiun } \\
\text { C1. Kurang banyak soal } \\
\text { evaluasinya dan terlalu } \\
\text { singkat }\end{array}$ & $\begin{array}{l}\text { A1. Diterima } \\
\text { B1. Diterima } \\
\text { C1. Diterima }\end{array}$ \\
\hline 5 & Daftar pustaka & $\begin{array}{l}\text { D1. Semakin banyak referensi } \\
\text { semaikn baik }\end{array}$ & $\begin{array}{l}\text { D1. Diterima } \\
\text { dengan } \\
\text { menambah } \\
\text { referensi }\end{array}$ \\
\hline 6 & Lain-lain & $\begin{array}{l}\text { A1. Lebih difokuskan pada } \\
\text { penulisan bahan } \\
\text { penjelasan materi jangan }\end{array}$ & $\begin{array}{l}\text { A1. Diterima } \\
\text { karena memang } \\
\text { diarahkan } \\
\text { menjadi bahan } \\
\text { ajar. }\end{array}$ \\
\hline
\end{tabular}

Hasil uji coba skala kecil menjunjukkan bahwa umpan balik mahasiswa cukup luas spektrumnya dari masalah teknis hingga substansial. Masalah teknis 
seperti spasi dan pilihan kata. Masalah substansial terkait dengan rumusan tujuan pembelajaran, isi, format evaluasi/tugas yang lebih memandirikan dan mengaktifkan mahasiswa serta penambahan ilustrasi gambar. Semua umpan balik mahasiswa bisa diterima dan dijadikan bahan untuk perbaikan dan pengembangan bahan ajar.

Hasil uji coba skala kecil dijadikan bahan untuk perbaikan bahan ajar. Setelah dilakukan perbaikan, selanjutnya dilakukan uji coba skala besar terhadap 12 orang mahasiswa dari berbagai angkatan yang dipilih berdasarkan penilaian peneliti terhadap kemampuan reseptifnya dari tingkat baik, cukup, dan kurang dari setiap angkatan. Berikut rekapitulasi hasil uji coba skala besar.

Tabel 3. Rekapitulasi Hasil Uji Coba Skala Besar

\begin{tabular}{|c|c|c|c|}
\hline No & Komponen & Umpan balik mahasiswa & Keputusan \\
\hline 1 & $\begin{array}{l}\text { Bagian depan } \\
\text { (cober, daftar isi, } \\
\text { kata pengantar) }\end{array}$ & $\begin{array}{l}\text { B1. Judul lebih dibuat } \\
\text { menarik lagi } \\
\text { B2. Judul membuat orang } \\
\text { tertarik untuk membacanya, } \\
\text { kata pengantar bagus sudah } \\
\text { ada penjelasannya } \\
\text { B3. Judul menarik pembaca } \\
\text { untuk menambah wawasan, } \\
\text { daftar isi sudah lengkap } \\
\text { mencakup semua bab yang } \\
\text { dijelaskan di bagian isi } \\
\text { B4. Daftar isi terlalu banyak } \\
\text { kata Madiun } \\
\text { B6. Cover ditambah gambar } \\
\text { yang lebih menarik } \\
\text { B7. Cukup menarik untuk } \\
\text { dibaca dan dipelajari } \\
\text { B8. Cover diberi gambar } \\
\text { yang lebih menarik } \\
\text { B9. Cover depan perlu } \\
\text { ditambah gambar-gambar } \\
\text { Sejarah Madiun } \\
\text { B10. Cover hendaknya } \\
\text { disertai gambar agar terlihat } \\
\text { lebih menarik } \\
\text { B11. Lebih baik cover } \\
\text { menggunakan gambar yang } \\
\text { menunjukkan ciri khas } \\
\text { Madiun } \\
\text { B12. Ditambah gambar yang } \\
\text { lebih menarik }\end{array}$ & $\begin{array}{lr}\text { B1-12. } & \text { Cover } \\
\text { belum } & \text { bisa } \\
\text { ditambah } & \text { gambar } \\
\text { yang } & \text { lebih } \\
\text { menarik } & \text { karena } \\
\text { belum } & \text { masuk } \\
\text { rancangan cetak }\end{array}$ \\
\hline 2 & $\begin{array}{l}\text { Tujuan } \\
\text { pembelajaran }\end{array}$ & $\begin{array}{l}\text { B2. Tujuan pembelajaran } \\
\text { sulit dipahami orang awam } \\
\text { seperti kata analisis } \\
\text { kompatatif, toponimi }\end{array}$ & $\begin{array}{l}\text { B2. Bahan ajar ini } \\
\text { memang } \\
\text { ditujukan untuk } \\
\text { mahasiswa }\end{array}$ \\
\hline
\end{tabular}




\begin{tabular}{|c|c|c|c|}
\hline & & $\begin{array}{l}\text { B3. Tujuan sudah jelas } \\
\text { B4. Dijelaskan lebih rinci } \\
\text { awal berdirinya Madiun } \\
\text { B5. Sudah sesuai dengan } \\
\text { manfaat sebagai bahan ajar } \\
\text { B6. Sudah terlampir dengan } \\
\text { baik } \\
\text { B8. Lebih detail } \\
\text { B9. Mahasiswa mampu } \\
\text { mendeskripsikan sejarah } \\
\text { Madiun } \\
\text { B10. Sudah sesuai dengan } \\
\text { pokok bahasan } \\
\text { B12. Perlu ditambah } \\
\text { pemberdayaan mahasiswa } \\
\text { bagi Sejarah Madiun }\end{array}$ & $\begin{array}{l}\text { sehingga } \\
\text { bahasanya } \\
\text { disesuaikan } \\
\text { dengan tingkat } \\
\text { perkembangan } \\
\text { bahasa } \\
\text { mahasiswa }\end{array}$ \\
\hline 3 & Isi per bab & $\begin{array}{l}\text { B2. Materi sudah bagus, } \\
\text { kalimat-kalimatnya mudah } \\
\text { dipahami oleh pembaca } \\
\text { B3. Isi sebaiknya } \\
\text { menggunakan bahasa yang } \\
\text { mudah dipahami. Materi } \\
\text { jangan terlalu banyak karena } \\
\text { kemampuan setiap individu } \\
\text { berbeda } \\
\text { B6. Sudah dirinci dan disertai } \\
\text { gambar, isi padat tapi jelas, } \\
\text { banyak mengandung nilai } \\
\text { B7. Lebih dipertajam atau } \\
\text { mendetail } \\
\text { B9. Sebaiknya ditunjukkan } \\
\text { sub babnya } \\
\text { B10. Dibuat sub bab agar } \\
\text { tidak membingungkan }\end{array}$ & $\begin{array}{l}\text { B9-B10. Diterima } \\
\text { dengan } \\
\text { menambahkan } \\
\text { sub bab yang } \\
\text { diperlukan }\end{array}$ \\
\hline 4 & Evaluasi/tugas & $\begin{array}{l}\text { B5. Sudah sesuai dengan isi } \\
\text { B6. Sudah diberikan per bab } \\
\text { sangat baik } \\
\text { B9. Disesuaikan dengan bab } \\
\text { yang dikaji } \\
\text { B10. Dibuat lebih bervariasi } \\
\text { agar pembelajaran lebih } \\
\text { menarik misal jigsaw, role } \\
\text { playinh } \\
\text { B11. Sudah cukup } \\
\text { B12. Sudah cukup }\end{array}$ & $\begin{array}{l}\text { B10. Metode } \\
\text { pembelajaran } \\
\text { tidak menjadi } \\
\text { bahasan dalam } \\
\text { bahan ajar ini. }\end{array}$ \\
\hline 5 & Daftar pustaka & $\begin{array}{l}\text { B1. Ditambah pustaka } \\
\text { B2. Sudah cukup mencakup }\end{array}$ & \\
\hline
\end{tabular}




\begin{tabular}{|c|c|c|c|}
\hline & & $\begin{array}{l}\text { beberapa ahli } \\
\text { B7. Perlu penambahan daftar } \\
\text { pustaka } \\
\text { B9. Sudah sesuai } \\
\text { B10. Lebih diperbanyak lagi } \\
\text { B11. Sudah lengkap }\end{array}$ & \\
\hline 6 & Lain-lain & $\begin{array}{l}\text { B4. Ditambah foto-foto yang } \\
\text { menggambarkan keadaan riil } \\
\text { B5. Ada beberapa kata belum } \\
\text { bisa dipahami sehingga harus } \\
\text { diberi penjelasan } \\
\text { B6. Sudah bagus sebagai } \\
\text { bahan ajar Sejarah Madiun. } \\
\text { Ingat } 5 \mathrm{R} \\
\text { B9. Perlu ditambahkan } \\
\text { gambar-gambar Sejarah } \\
\text { Madiun Sebaiknya dalam } \\
\text { B12. ditambah } \\
\text { pembelajaran den } \\
\text { dengan media visual ataupun } \\
\text { audio. }\end{array}$ & $\begin{array}{l}\text { Diterima dengan } \\
\text { menambah } \\
\text { gambar-gambar }\end{array}$ \\
\hline
\end{tabular}

Hasil uji coba skala besar menunjukkan bahwa komponen-komponen bahan ajar sudah banyak yang bisa diterima oleh mahasiswa. Beberapa hal teknis seperti penambahan gambar dan sub bab bisa diterima. Hasil uji coba skala besar dijadikan bahan untuk perbaikan dan pengembangan sehingga dihasilkan produk final bahan ajar Mata Kuliah Sejarah Madiun.

\section{Penutup}

\section{A. Simpulan}

Berdasarkan pengumpulan informasi dan identifikasi masalah terkait dengan bahan ajar Mata Kuliah Sejarah Madiun di Program Studi Pendidikan Sejarah IKIP PGRI MADIUN. Data dikumpulkan dari dosen pengampu mata kuliah Sejarah Madiun. Beberapa masalah yang teridentifikasi adalah minimnya sumber, masalah pembabakan yang kurang komperehensif, dan kurangnya data kekinian. Masalahmasalah tersebut selanjutnya menjadi acuan untuk mengembangkan bahan ajar Mata Kuliah Sejarah Madiun.

Berdasarkan identifikasi masalah di atas, maka dibuat draf awal bahan ajar Mata Kuliah Sejarah Madiun yang disusun berdasarkan temuan masalah-masalah di lapangan. Setelah melalui uji ahli, uji skala kecil dan skala besar, maka dihasilkan produk akhir bahan ajar Mata Kuliah Sejarah Madiun yang siap dipublikasikan dan diimplementasikan dalam pembelajaran.

\section{B. Saran}

Agar naskah bahan ajar Mata Kuliah Sejarah Madiun mampu mendukung kemandirian belajar dan efektivitas pembelajaran, maka keaktifan mahasiswa menjadi penting dalam mengikuti perkuliahan. Demikian pula dosen pengampu 
mata kuliah diharapkan dapat memfasilitasi belajar mahasiswa agar lebih memiliki kemandirian belajar melalui bahan ajar tersebut.

\section{Daftar Pustaka}

Association for Educational Communications and Technology. 1986. Definisi Teknologi Pendidikan. Jakarta: CV Rajawali.

Achmad Ali. 2004. Merangkul Cahaya Menata Mutiara Madiun. Madiun: Pemerintah Kota Madiun.

Charles, Anderson David. 2003. Peristiwa Madiun 1948. Yogyakarta: Media Pressindo.

Hariyono. 1995. Mempelajari Sejarah Secara Efektif. Jakarta: Pustaka Jaya.

Kemdiknas. 2008. Sosialisasi KTSP: Pengembangan Bahan Ajar. Jakarta: Kemdiknas RI.

Kuntowijoyo. 1994. Metodologi Sejarah. Yogyakarta: Tiara Wacana

Pannen, P., Purwanto. 2001. Penulisan Bahan Ajar. Jakarta: Dirjen Dikti Depdiknas

Pemkab Madiun. 1980. Sejarah Madiun. Madiun: Pemerintah Kabupaten Madiun

Peraturan Menteri Pendidikan Nasional Republik Indonesia Nomor 2 tahun 2008 Tentang Buku

Ricklefs, M.C. 1998. Sejarah Indonesia Modern, terjemah Dharmono Hardjowidjono Yogyakarta: Gadjahmada University Press.

Sartono Kartodirdjo. 1992. Pendekatan Ilmu Sosial Dalam Metodologi Sejarah. Jakarta: Gramdia.

Soe Hok Gie. 1999. Orang-orang di Persimpangan Kiri Jalan. Yogyakarta: Bentang Budaya.

Swajati. 2005. Belajar Sendiri: Membuat CD-Multimedia Interaktif untuk Bahan Ajar E-Learning. Jakarta: PT Elek Media Komputindo.

Taufik Abdullah. 1985. Sejarah Lokal di Indonesia. Yogyakarta: Gadjahmada University Press.

Tim. 2003. Sejarah Berdirinya Kota Madiun. Madiun: Panitia Penelitian Hari Jadi Kota Madiun. 